\title{
Characterization of Actin and Myosin in the Developing Stomach
}

\author{
M. AYAS, K. N. BITAR, AND C. HILLEMEIER \\ University of Michigan Medical School, Ann Arbor, Michigan 48109-0658
}

\begin{abstract}
During growth and development, dietary intake changes from
being predominantly liquid in the newborn period to mixed solid liquid meals. These alterations in diet vary the functional demands placed on the stomach. It has been shown that, during development, smooth muscle of the stomach undergoes changes in the mechanism responsible for the contractile process. In this study, we have investigated the possibility that there are structural changes in two of the major proteins that are responsible for generation of force during smooth muscle contraction: actin and myosin. Actin and myosin were identified in newborn kittens (1 wk old) and adult gastric smooth muscle using one-dimensional SDS-PAGE. Although both the antrum and fundus of the kitten have significantly smaller total amounts of actin and myosin per mg protein than the adult, the ratio of actin to myosin is not significantly different between the age groups. Two different
\end{abstract}

myosin heavy chain (MHC) isoforms, MHC1 (205 kD) and MHC2 $(200 \mathrm{kD})$, were identified in all tissues. The relative amount of $\mathrm{MHC1}$ remained constant during maturation of the stomach. We observed an increase in the amount of $\mathrm{MHC} 2$ in the adult, which resulted in a decreased ratio of MHC1 to $\mathrm{MHC} 2$ in the adult. We postulate that the decreased quantity of actin and myosin in the kitten stomach and the observed changes in the ratio of the $\mathrm{MHC}$ isoforms are related to changes in the gastric motor that occur during growth and development. (Pediatr Res 37: 202-206, 1995)

Abbreviations
PMSF, phenylmethyl sulfanyl fluoride
$\boldsymbol{\beta}$ ME, $\beta$-mercaptoethanol
MHC, myosin heavy chain

The changes in dietary constituents during growth and development from predominantly liquid to mixed solid liquid meals places an increasing burden on the stomach that is required to triturate these solids and empty them from the stomach. The fundus or proximal portion of the stomach is responsible for the storage and emptying of gastric foodstuffs, whereas the antrum reduces the size of ingested solids and facilitates emptying (1). There is a growing body of experimental evidence suggesting that functional characteristics of smooth muscle in the stomach undergo changes that parallel these alterations in dietary milieu. The frequency and amplitude of contractions in the canine stomach increase during the newborn period (2). The in vitro force-generating capacity of smooth muscle from the stomach of newborn rabbits is less than that of adult gastric muscle, and this reduction in forcegenerating capacity did not appear to be accounted for by changes in receptor function $(3,4)$. In addition to these quantitative differences in ability to generate force, we have recently reported that isolated muscle cells from the antrum of the adult cat use intracellular $\mathrm{Ca}^{2+}$ stores that are not available for kitten antral cells (5).

Received October 7, 1993; accepted September 23, 1994.

Correspondence: Craig Hillemeier, M.D., University of Michigan Medical School,

Pediatric Gastroenterology, 107 Simpson Dr./0200, Ann Arbor, MI 48109-0200.

Supported by NIH R01 HD20054 and R01 DK42876.
Actin and myosin are two of the major structural proteins involved in the contractile machinery of the cell. The generation of tension during muscle contraction is the result of the interaction between myosin heads and adjacent actin filaments (6). Previous studies have suggested that changes in the absolute amount and relative abundance of isoforms of these contractile proteins may be associated with alterations in the functional characteristics of muscle (7). The purpose of our study was to determine what quantitative and qualitative changes occur in actin and myosin during development of the newborn stomach. Our data indicate that although the ratio of actin to total MHC remains constant during growth and development, the relative amounts of actin and myosin per mg of protein increase with age and there is a change in the distribution of $\mathrm{MHC}$ isoforms.

\section{METHODS}

Seven-d-old kittens and adult cats were used as animal models after the animals were anesthetized with xylozine intramuscularly followed by ketamine. The animal's abdomen was opened with a midline incision exposing the stomach. The animal was then killed by injecting Beuthanasia into the heart. The stomach was removed and opened along the lesser curvature. The fundus was identified as $1 \mathrm{~cm}^{2}$ of tissue below the lower esophageal segment. The antrum was taken as $1 \mathrm{~cm}^{2}$ of 
the tissue adjacent to the pylorus. The mucosa was removed with the use of a dissecting microscope. The tissue was cleaned of all visible adherent tissue on the adventitial and serosal side. The dissection was carried out at $4^{\circ} \mathrm{C}$ in a dish containing oxygenated Kreb's buffer $(116.6 \mathrm{mM} \mathrm{NaCl}, 21.9 \mathrm{mM}$ $\mathrm{NaHCO}_{3}, 1.2 \mathrm{mM} \mathrm{KH}_{2} \mathrm{PO}_{4}, 5.4 \mathrm{mM}$ glucose, $1.2 \mathrm{mM} \mathrm{MgCl}$, $\mathrm{pH} 7.4$ ), with $1 \% \beta \mathrm{ME}, 0.1 \mathrm{mM}$ PMSF, $1 \mu \mathrm{g} / \mathrm{mL}$ pepstatin A, and $5 \mu \mathrm{g} / \mathrm{mL}$ leupeptin. The outer longitudinal layer was removed using a Stadie-Riggs tissue slicer and the wet weight of the tissue determined.

Similar to methods used previously, the tissue was homogenized with 35 volumes of extraction buffer $\left(25 \mathrm{mM} \mathrm{NaPO}_{4}\right.$, $\mathrm{pH} 7$ ) with $1 \% \beta \mathrm{ME}, 0.1 \mu \mathrm{M}$ PMSF, $1 \mu \mathrm{g} / \mathrm{mL}$ pepstatin $\mathrm{A}$, and $5 \mu \mathrm{g} / \mathrm{mL}$ leupeptin (8-10). SDS was added to a $1 \%$ concentration. The homogenate was extracted on ice for $2 \mathrm{~h}$, incubated at $37^{\circ} \mathrm{C}$ for $15 \mathrm{~min}$, then centrifuged for $15 \mathrm{~min}$ at $800 \times \mathrm{g}$, and the supernatant was removed (S1). Then the pellet was rehomogenized in the same volume of extraction buffer, SDS was added, and the homogenate was extracted overnight at $4^{\circ} \mathrm{C}$ and incubated at $37^{\circ} \mathrm{C}$ for $15 \mathrm{~min}$. It was then centrifuged and the supernatant removed (S2). S1 and S2 were pooled, and aliquots were taken for SDS-PAGE and protein determination. The pellet was then rehomogenized and extracted for $2 \mathrm{~h}$ and incubated at $37^{\circ} \mathrm{C}$ for $15 \mathrm{~min}$. The $\mathrm{S} 3$ and pellet 3 were removed for SDS-PAGE and protein determination.

The denaturing SDS-PAGE of Laemmli (11) was used to study heavy chain isoforms of myosin and actin. The homogenates were mixed with sample buffer in a 1:1 ratio and boiled for $2 \mathrm{~min}$. A $4.5 \%$ acrylamide gel (1:29 bis/acrylamide) was used to separate MHC isoforms and actin. An Idea Scientific (Minneapolis, MN) mini gel cell was used; the gel thickness was $0.75 \mathrm{~mm}$, and the gel was run for $45 \mathrm{~min}$ at $30 \mathrm{~mA}$ per gel slab (constant current). Molecular weight markers were used to help identify the myosin and actin $(205-\mathrm{kD}$ myosin and $45-\mathrm{kD}$ actin from Sigma Chemical Co., St. Louis, MO, prestained molecular weight marker from Amersham Corp., Arlington Heights, IL).

The gels were stained with Coomassie brilliant blue and destained with 5\% acetic acid and $10 \%$ methanol until clear. They were scanned using quick scan densitometry. The amounts of the MHC bands and actin bands were calculated by comparing their peaks to a peak of a known amount of a standard (actin).

Total protein (collagenous and noncollagenous) measurements were performed using bicinchoninic acid, as described previously (12), on all homogenates. Reagents for this assay were obtained from Pierce Chemical Company (Rockford, IL). When noncollagenous protein measurements were performed on the tissue, they were determined by the procedure of Lilienthal et al. (13). Briefly, smooth muscle tissue was extracted in $0.05 \mathrm{~N} \mathrm{NaOH}$ at room temperature for $24 \mathrm{~h}$ before protein determinations.

Anti-smooth muscle myosin IgG preparation. Polyclonal myosin antibodies to rabbit uterine smooth muscle were purchased from Sigma (product M-7648). The IgG was purified by chromatography on DEAE Affi-Gel blue agarose gel (Sigma Chemical Co.) (14). An Econo-pac serum IgG purification kit was purchased from Bio-Rad Laboratories (Richmond, CA).
The $3 \mathrm{~mL}$ of serum were generally desalted using an Econopac 10 DG desalting column (Bio-Rad Laboratories). Then the IgG was purified using an Econo-pac serum IgG purification column. The IgG was eluted using an application buffer $(0.02$ $\mathrm{M}$ Tris- $\mathrm{HCl}$, $\mathrm{pH} 8.0$, containing $0.028 \mathrm{M} \mathrm{NaCl}$ ), and it was collected in $2-\mathrm{mL}$ fractions. The absorbence at $280 \mathrm{~nm}$ of each fraction was determined using a spectrophotometer (UV/VIS, Perkin-Elmer Corp., Norwalk, CT) and the effluent tubes containing the unbound protein peaks were combined.

Immunoblotting. Protein on SDS-PAGE was transblotted onto nitrocellulose paper and assayed. The Mini Gene immunoblotter from Idea Scientific was used. The transfer buffer was composed of $25 \mathrm{mM}$ Tris base, $192 \mathrm{mM}$ glycine base, $10 \%$ (vol/vol) methanol, and $0.05 \%$ SDS. The immunoblotting was carried out at $22 \mathrm{~V}$ for $90 \mathrm{~min}$. Part of the nitrocellulose paper was stained with a mixture of Pelikan fountain india ink in PBS-Tween to confirm protein transfer. The nitrocellulose was then blocked at $37^{\circ} \mathrm{C}$ for $1 \mathrm{~h}$, rinsed with PBS, and incubated with myosin antibodies overnight at $4^{\circ} \mathrm{C}$. It was then rinsed in PBS and exposed to peroxidase-conjugated secondary antibodies. After remaining for $2 \mathrm{~h}$ at room temperature, the treated nitrocellulose was washed in PBS and developed using a developer solution composed of $2 \mathrm{~mL}$ of 4-Cl naphtol stock ( $0.3 \%$ in pure methanol), $8 \mathrm{~mL}$ of distilled $\mathrm{H}_{2} \mathrm{O}$, and $50 \mu \mathrm{L}$ of $\mathrm{H}_{2} \mathrm{O}_{2}$ for $5 \mathrm{~min}$. It was then rinsed with distilled water and air dried overnight in a dark area.

\section{RESULTS}

Two MHC isoforms were identified, one at $205 \mathrm{kD}$ (MHC1), and one at $200 \mathrm{kD}$ (MHC2). These isoforms were present in all the tissues studied (Fig. 1). Both bands reacted positively to

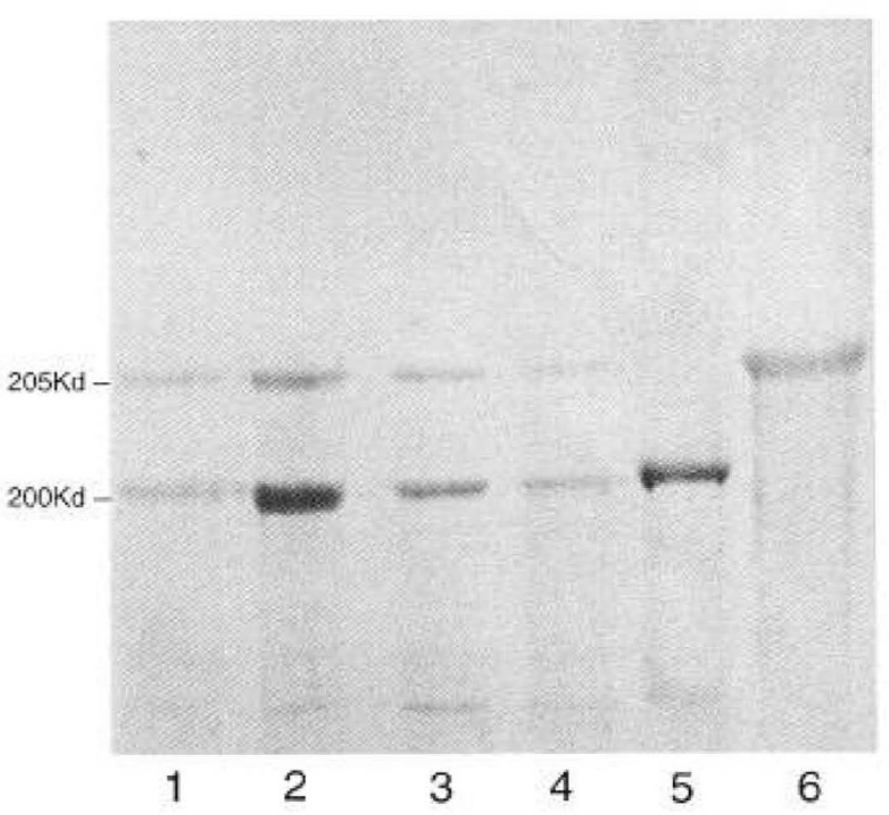

Figure 1. Coomassie stain of protein from antrum and fundus. Proteins from the respective ages and regions are separated by a 7\% SDS-PAGE and stained with Coomassie brilliant blue. The figure shows the presence of the two isoforms of MHC in the antrum and fundus of newborn and adult cats. Lane 1 , adult fundus; lane 2, adult antrum; lane 3, kitten antrum; lane 4, kitten fundus; lane 5, 200-kD molecular mass marker; and lane 6, 205-kD molecular mass marker. 
purified myosin antibody after the protein was transferred to nitrocellulose paper (Fig. 2).

Although the amount of $\mathrm{MHC} 1$ (expressed as $\mathrm{mg} / \mathrm{g}$ wet weight) was unchanged with maturation from the newborn to adult in both the antrum (7.03 \pm 0.97 versus $7.32 \pm 0.19)$ and fundus ( $3.96 \pm 0.65$ versus $4.83 \pm 0.47$ ), the amount of MHC2 (expressed as $\mathrm{mg} / \mathrm{g}$ wet weight) did increase significantly with advancing age in both the antrum (11.45 \pm 0.81 versus $21.1 \pm$ $2.58 p \leq 0.05)$ and fundus $(5.4 \pm 0.65$ versus $9.73 \pm 0.83$, $p \leq 0.05$ ). This results in a decrease in the ratio of MHC1 to MHC2 with maturation in both the fundus and antrum (Fig. 3).

Table 1 expresses the total amount of protein and noncollagenous protein present in the antrum and fundus of the newborn and adult cat per $g$ wet weight. Although there is more total protein per $\mathrm{g}$ wet weight present in the newborn of both the fundus and antrum, this is not true when one examines the ratio of noncollagenous protein to $g$ wet weight. This suggests that the newborn fundus has more collagenous protein than the adult, but noncollagenous protein concentrations are similar. When the concentration of both actin and myosin are examined, it is found that the newborn has a significantly lower amount in both the antrum and fundus (Table 2). This difference occurs whether actin and myosin are expressed as mg of protein per $\mathrm{g}$ wet weight or $\mathrm{mg}$ of protein per $\mathrm{g}$ noncollagenous protein. When the ratios of actin to myosin from the newborn and adult in each region are compared, they are similar with an actin/myosin ratio of 2:1 in the newborn fundus, 1:7 in the adult fundus, 2:1 in the newborn antrum, and 1:8 in the adult antrum.

\section{DISCUSSION}

Muscle of various types and locations has been shown to have a reduced ability to generate stress (force/cross-sectional area) during the newborn period. Myocardium undergoes changes that lead to an increase in the ability of the muscle to generate force as development proceeds from fetus to adult (16). Similar changes have been noted in gastrointestinal smooth muscle, where strips of rat and rabbit newborn gastric circular muscle have been shown to generate less stress than the adult gastric circular muscle $(3,4)$.

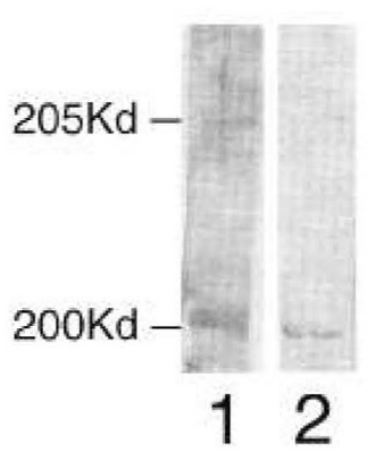

Figure 2. Immunoblot of $\mathrm{MHC}$. This figure shows $\mathrm{MHC1}$ and $\mathrm{MHC} 2$ of adult antrum (lane 1 ) and kitten fundus (lane 2) after being transferred from $4.5 \%$ acrylamide onto nitrocellulose paper. The isoforms were exposed to prepared myosin MAb to rabbit uterine smooth muscle. The antibodies were then detected by secondary staining using peroxidaseconjugated antibodies.

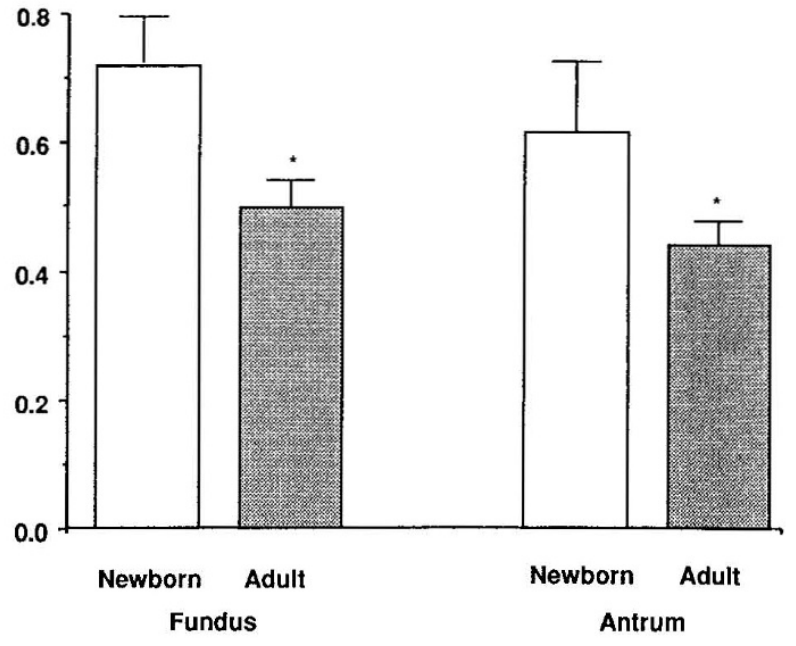

Figure 3. Ratio of $\mathrm{MHC} 1$ and $\mathrm{MHC} 2$ in antrum and fundus. The ratio of MHC1 to MHC2 is significantly less in both the antrum and fundus of the adult cat than in the kitten $\left({ }^{*}, p \leq 0.05\right)$. This occurs because, although the amount of $\mathrm{MHC} 1$ is unchanged during development, the amount of MHC2 increases.

Table 1. Total and noncollagenous protein in newborn and adult cats

\begin{tabular}{lcc}
\hline & $\begin{array}{c}\text { Total protein } \\
(\mathrm{mg} / \mathrm{g} \text { wet wt) }\end{array}$ & $\begin{array}{c}\text { Noncollagenous protein } \\
(\mathrm{mg} / \mathrm{g} \text { wet wt) }\end{array}$ \\
\hline Newborn fundus & $340.3 \pm 58.6$ & $57.5 \pm 7.4$ \\
Adult fundus & $231.1 \pm 34.3$ & $51.6 \pm 1.5$ \\
Newborn antrum & $321.6 \pm 60.0$ & $69.5 \pm 11.0$ \\
Adult antrum & $271.5 \pm 7.4$ & $81.8 \pm 6.6$ \\
\hline
\end{tabular}

The total protein and noncollagenous protein are expressed per $g$ wet weight in the antrum and fundus of the newborn and adult cat. All values expressed are the average of $n \geq 3$ animals.

Table 2. Actin and myosin content of newborn and adult cat stomach

\begin{tabular}{lcc}
\hline & $\mathrm{mg}$ actin/g wet wt & $\mathrm{mg}$ myosin/g wet wt \\
\hline Newborn fundus & $16.26 \pm 1.64^{*}$ & $9.4 \pm 0.8 \dagger$ \\
Adult fundus & $29.48 \pm 5.9^{*}$ & $14.56 \pm 1.3 \dagger$ \\
Newborn antrum & $34.47 \pm 1.09^{*}$ & $18.48 \pm 1.5 \dagger$ \\
Adult antrum & $52.40 \pm 10.3^{*}$ & $28.42 \pm 2.1 \dagger$ \\
\hline
\end{tabular}

The actin and myosin content of the fundus and antrum in newborn and adult cats are expressed both as $\mathrm{mg} / \mathrm{g}$ wet weight of tissue and $\mathrm{mg} / \mathrm{g}$ noncollagenous. All values expressed are for $n \geq 3$ animals. The unpaired $t$ test is used to compare values from the different aged cats in the same region (i.e. kitten fundus is compared with adult fundus).

$* p \leq 0.025$.

$\dagger p \leq 0.005$.

In our study, we observed that the amounts of actin and myosin $(\mu \mathrm{g} / \mathrm{mg}$ protein) present in antral or fundic gastric smooth muscle both increase with age. It is likely that higher amounts of these contractile proteins would be correlated with an increase in force generation, inasmuch as the cross-bridge interaction between these two proteins is thought to be the final common pathway for muscle contraction (17). Similar findings have been made in the rat aorta, where increasing amounts of actin and myosin during the newborn period temporally correlate with increased force generation (10). The finding that the 
ratio of actin to myosin remains unchanged in the smooth muscle of the stomach during development indicates proportional increases that would suggest the intracellular ratio of these two proteins remains constant. The observed increase in the actin and myosin content during maturation of feline gastric smooth muscle could therefore result from either a proportional increase in the cellular concentration of these contractile proteins or increases in cell density.

Myosin is composed of two heavy chains and two pairs of light chains of two different types. Each heavy chain consists of an N-terminal globular head and a C-terminal, rod-like, $\alpha$-helical tail region. The globular head of the myosin contains actin-stimulated ATPase activity, the regulation of which controls the actual sliding interaction between the two proteins that results in smooth muscle shortening. It has previously been noted that the heavy chain of myosin can migrate to more than one position on one-dimensional SDS-PAGE. Those forms of MHC, which vary slightly in molecular weight, are called isoforms.

Our data show a change in MHC isoform distribution. We have found two isoforms of MHC in feline gastric smooth muscle that correspond to their speed of migration and can be classified as $\mathrm{MHC1}$ and $\mathrm{MHC} 2$. Although the relative amount of $\mathrm{MHC} 1$ remains constant during development of the stomach, there is an increased amount of MHC2 in the adult, resulting in a decreased ratio of $\mathrm{MHC1}$ to $\mathrm{MHC} 2$ during growth and development. Changes in MHC isoforms may be important because of the way in which they affect the contractile function of the muscle. These changes have been found in response to changes in the environment that alter the demands on the muscle for contraction or in maturational processes.

In response to chronic heart overload in rodents, a shift in MHC occurred with an increase in the slow MHC isoform V3 and a decrease in the fast MHC isoform V1 (26). Similar changes have been noted in the human atrial smooth muscle but not in ventricular muscle $(7,23)$. A change in MHC isoform distribution has been seen in the rodent ventricle with hypothyroidism and in skeletal muscle after hypertrophy of chicken slow muscle from repeated use $(19,27)$.

Changes in distribution of MHC isoforms have been reported in skeletal, myocardial, and smooth muscle $(18-20)$ during growth and development. In the rodent ventricle, the slow migrating MHC isoform is predominant in fetal life, whereas the faster migrating $\mathrm{MHC}$ is more prevalent during adult life (21). In the pig tracheal smooth muscle, there is a decrease in the ratio of $\mathrm{MHC} 1$ to $\mathrm{MHC} 2$ during maturation (24), whereas similar work on human tracheal smooth muscle failed to show any change in $\mathrm{MHC}$ isoform with maturation (25).

The changes that we see in MHC distribution in the feline stomach occur during a maturational process and a time of changing functional demands on the stomach. Dietary intake changes from a liquid to a mixed solid liquid diet requiring the adult stomach to triturate solids, a task the newborn stomach is not called on to perform.

In skeletal and cardiac muscle there are indications that different MHC isoforms have different ATPase activity (28, 29). This could significantly alter the contractile properties of a muscle, because myosin ATPase activity is a major factor in controlling the velocity of contraction (shortening velocity) (29). In the rabbit heart, hypothyroidism increases the relative amount of slow MHC isoform and is associated with a slower, more economical contraction, whereas hyperthyroidism is associated with an increase in the faster isoform and a more rapid contraction that is less economical in terms of energy expenditure (27). It is also possible that these differences in MHC isoform distribution that affect ATPase activity could affect the ultimate ability of smooth muscle to generate tension (30). Additional studies are needed to evaluate gastric MHC ATPase in the developing feline stomach and the relationship to contractile characteristics.

In conclusion, our data indicate that both feline antral and fundic gastric smooth muscle experience a change in the amount of actin and myosin present and in the ratio of MHC isoforms that are present during growth and development. It is conceivable that these quantitative and qualitative changes in actin and myosin are related to changes in functional muscle characteristics that are required during growth and development to adequately handle changes in dietary intake.

\section{REFERENCES}

1. Read NW, Houghton LA 1989 Physiology of gastric emptying and pathophysiology of gastroparesis. Gastroenterol Clin North Am 18:359-373

2. Malloy MH, Morriss FH, Denson SE, Weisbrot NW, Lichtenberger LM, Adcock III EW 1979 Neonatal gastric motility in dogs: maturation and response to pentagastrin. Am J Physiol 236:E562-E566

3. Zitterman J, Ryan JP 1990 Development of gastric antral smooth muscle contractility in newborn rabbits. Am J Physiol 258:G571-G575

4. Tomosoma T, Yagi H, Kimura S, Snape WJ, Hyman PE 1989 Developmental changes in agonist mediated gastric smooth muscle cells in the rabbit. Pediatr Res 26:458-461

5. Hillemeier AC, Bitar KN, Biancani P 1991 Developmental characteristics of the kitten antrum. Gastroenterology 101:339-343

6. Albert B, Bray D, Lewis J, Raff M, Roberts K, Watson JD 1989 Molecular Biology of the Cell. Garland Publishing, New York

7. Swynghedauw B 1986 Developmental and functional adaptation of contractile proteins in cardiac and skeletal muscles. Physiol Rev 66:710-771

8. Bower RL, Dubinsky WP, Weisbrodt NW 1990 Actomyosin, collagen, and succinate dehydrogenase determinations in opossum esophageal muscles. J Gastrointest Motil 2:209-215

9. Bower RL, Eeckhout C, Weisberodt NW 1986 Actomyosin, collagen, and cell hypertrophy in intestinal muscle after jejunoileal bypass. Am J Physiol 250:G70-G75

10. Seidel CL, Murphy RA 1979 Changes in rat aortic actomyosin content with maturation. Blood Vessels 16:98-108

11. Laemmli UK 1970 Cleavage of structural proteins during the assembly of the head of bacteriophage T4. Nature 227:680-685

12. Smith PK, Krohn RI, Hermanson GT, Mallia AK, Gartner FH, Provenzano MD, Fujimoto EK, Goeke NM, Olson BJ, Klenk DC 1985 Measurement of protein using bicinchoninic acid. Anal Biochem 150:76-85

13. Lilienthal JL, Zierler KL, Folk BP, Buka R, Riley MR 1950 A reference base and system for analysis of muscle constituents. J Biol Chem 182:501-509

14. Axelsen NT, Koll J, Weeke B 1973 A manual of quantitative immunoelectrophoresis. Scand J Immunol 2(suppl 1): 95-99

15. Towbin H, Staehelin T, Gordon J 1979 Electrophoretic transfer of proteins from polyacrylamide gels to nitrocellulose sheets: procedure and some applications. Proc Natl Acad Sci USA 76:4350-4354

16. Lamsback WJ 1990 Fetal and Neonatal Cardiology. WB Saunders Co, New York

17. Johnson LR (ed) 1987 Physiology of the Gastrointestinal Tract. Raven Press, New York

18. Rovner AS, Thompson MM, Murphy RA 1986 Two different heavy chains are found in smooth muscle myosin. Am J Physiol 250:C861-C870

19. Kennedy JM, Kamel S, Tambone WW, Vrbova G, Zak R 1986 The expression of myosin heavy chain isoforms in normal and hypertrophied chicken slow muscle. $J$ Cell Biol 103:977-983

20. Sartore S, De Marzo N, Borrione AC, Zanellato AM, Saggin L, Fabbri L, Schiaffino S 1989 Myosin heavy-chain isoforms in human smooth muscle. Eur J Biochem 179:79-85

21. Lompre AM, Nadal-Ginard B, Mahdavi V 1984 Expression of the cardiac ventricular alpha- and beta-myosin heavy-chain genes is developmentally and hormonally regulated. J Biol Chem 259:6437-6446

22. Schwartz K, Lompre AM, Bouveret P, Wisnewsky C, Whalen RG 1982 Comparisons of rat cardiac myosins at fetal stages in young animals and in hypothyroid adults. $\mathrm{J}$ Biol Chem 257:14412-11418 
23. Schier JJ, Adelstein RS 1982 Structural and enzymatic comparison of human cardiac muscle myosins isolated from infants, adults, and patients with hypertrophic cardiomyopathy. J Clin Invest 69:816-825

24. Mohammad MA, Sparrow MP 1988 Changes in myosin heavy chain stoichiometry in pig tracheal smooth muscle during development. FEBS Lett 228:109-112

25. Mohammad MA, Sparrow MP 1989 The distribution of heavy-chain isoforms of myosin in airways smooth muscle from adult and neonate humans. Biochem $\mathrm{J}$ 260:421-426

26. Lompre AM, Schwartz K, d'Albis A, Lacombe G, Van Thiem N, Swynghedauw B 1979 Myosin isoenzyme redistribution in chronic heart overload. Nature 282:105107

27. Holubarsch C, Goulette RP, Litten RZ, Martin BJ, Mulieri LA, Alpert NR 1985
The economy of isometric force development, myosin isoforms pattern and myofibrillar ATPase activity in normal and hypothyroid rat myocardium. Circ Res $56: 78-86$

28. Schwartz K, Carrier L, Lompre AM, Mercadier JJ, Boheler KR 1992 Contractile proteins and sarcoplasmic reticulum calcium-ATPase gene expression in the hypertrophied and failing heart. Basic Res Cardiol 87:285-290

29. Barany M 1967 ATPase activity of myosin correlated with speed of muscle shortening. J Gen Physiol 50:197-218

30. Kenney RE, Hoar PE, Kerrick WG 1990 The relationship between ATPase activity, isometric force and myosin light-chain phosphorylation and thiophosphorylation in skinned smooth muscle fiber bundles from chicken gizzard. J Biol Chem 265:86428649 